\title{
Front Matter: Volume 11800
}

, "Front Matter: Volume 11800," Proc. SPIE 11800, Low-Dimensional Materials and Devices 2021, 1180001 (23 August 2021); doi: 10.1117/12.2606431

SPIE Event: SPIE Nanoscience + Engineering, 2021, San Diego, California, United SPIE. States 


\section{PROCEEDINGS OF SPIE}

\section{Low-Dimensional Materials and Devices 2021}

Nobuhiko P. Kobayashi

A. Alec Talin Albert V. Davydov

M. Saif Islam

Editors

1-5 August 2021

San Diego, California, United States

Sponsored and Published by

SPIE 
The papers in this volume were part of the technical conference cited on the cover and title page. Papers were selected and subject to review by the editors and conference program committee. Some conference presentations may not be available for publication. Additional papers and presentation recordings may be available online in the SPIE Digital Library at SPIEDigitalLibrary.org.

The papers reflect the work and thoughts of the authors and are published herein as submitted. The publisher is not responsible for the validity of the information or for any outcomes resulting from reliance thereon.

Please use the following format to cite material from these proceedings:

Author(s), "Title of Paper," in Low-Dimensional Materials and Devices 2021, edited by Nobuhiko P. Kobayashi, A. Alec Talin, Albert V. Davydov, M. Saif Islam, Proc. of SPIE 11800, Seven-digit Article CID Number (DD/MM/YYYY); (DOI URL).

ISSN: 0277-786X

ISSN: 1996-756X (electronic)

ISBN: 9781510644380

ISBN: 9781510644397 (electronic)

Published by

SPIE

P.O. Box 10, Bellingham, Washington 98227-0010 USA

Telephone +1 3606763290 (Pacific Time)

SPIE.org

Copyright (C) 2021 Society of Photo-Optical Instrumentation Engineers (SPIE).

Copying of material in this book for internal or personal use, or for the internal or personal use of specific clients, beyond the fair use provisions granted by the U.S. Copyright Law is authorized by SPIE subject to payment of fees. To obtain permission to use and share articles in this volume, visit Copyright Clearance Center at copyright.com. Other copying for republication, resale, advertising or promotion, or any form of systematic or multiple reproduction of any material in this book is prohibited except with permission in writing from the publisher.

Printed in the United States of America by Curran Associates, Inc., under license from SPIE.

Publication of record for individual papers is online in the SPIE Digital Library.

\section{SP|E. DIGITAL}

Paper Numbering: A unique citation identifier (CID) number is assigned to each article in the Proceedings of SPIE at the time of publication. Utilization of CIDs allows articles to be fully citable as soon as they are published online, and connects the same identifier to all online and print versions of the publication. SPIE uses a seven-digit CID article numbering system structured as follows:

- The first five digits correspond to the SPIE volume number.

- The last two digits indicate publication order within the volume using a Base 36 numbering system employing both numerals and letters. These two-number sets start with 00, 01, 02, 03, 04, 05, 06, 07, 08, 09, 0A, OB ... 0Z, followed by 10-1Z, 20-2Z, etc. The CID Number appears on each page of the manuscript. 


\title{
Contents
}

\author{
LOW-DIMENSIONAL DEVICES AND APPLICATIONS
}

11800 OF Controlling light penetration depth to amplify the gain in ultra-fast silicon APDs and SPADs using photon-trapping nanostructures [11800-41]

$1180001 \quad$ Micro-photoluminescence characterisation of structural disorder in resonant tunneling diodes for THz applications [11800-10]

SILICON AND III-V SEMICONDUCTOR NANOWIRES

11800 OR Correlating spectroscopic and nanoscale structural properties in quantum well tubes III-V nanowires (Invited Paper) [1 1800-6]

11800 OS Silicon nanowires: a building block for future technologies (Invited Paper) [11800-15]

OPTICAL, ELECTRONIC AND THERMAL PROPERTIES OF LOW-DIMENSIONAL MATERIALS

1180013 Lead halide perovskite nanocrystals: optical properties and nanophotonics (Invited Paper) [11800-33]

$1180014 \quad$ Near-field microwave microscopy of nanostructured materials: modeling and experiment (Invited Paper) [1 1800-40]

\section{POSTER SESSION}

1180016 Effects of numbers of wells on optical properties of periodic InGaN graded structure [11800-32]

1180018 Impact of GaAsN capping on strain and quantum confinement in vertically coupled InAs/GaAs quantum dots [11800-9]

1180019 Effect of variation in Sb composition in In0.18 Ga0.82AsYSb 1 -Y capping layer on InAs StranskiKrastanov (SK) QDs in strain coupled Stranski-Krastanov (SK) on submonolayer (SML) QDs heterostructures [11800-11]

$118001 \mathrm{~A}$ Improvement in optical and elemental properties of spin-on phosphorus doped ZnO film [11800-17]

11800 1B Doping of ZnMgO with phosphorus by spin-on dopant technique [11800-23]

$118001 \mathrm{C}$ Fine-tuning of electron Eigen energy states in $\mathbf{G a A s} \mathbf{s}_{-\mathrm{x}} \mathbf{N}_{\mathbf{x}}$ capped InAs sub-monolayer quantum dots [11800-28] 
Proc. of SPIE Vol. $118001180001-4$ Downloaded From: https://www.spiedigitallibrary.org/conference-proceedings-of-spie on 26 Apr 2023
Terms of Use: https://www.spiedigitallibrary.org/terms-of-use 